\title{
Shallow-water occurrence of Wiwaxia in the middle Cambrian of the Barrandian area, Czech Republic
}

Oldřich Fatka, Petr Kraft, and Michal Szabad

Acta Palaeontologica Polonica 56 (4), 2011: 871-875 doi: http://dx.doi.org/10.4202/app.2009.0052

Isolated sclerites of the genus Wiwaxia are reported from shale interlayers in lower levels of middle Cambrian (unnamed 3rd Series of Cambrian) Buchava Formation in the Skryje-Týřovice Basin in the Czech Republic interpreted

as shallow-water sediments. Geographic distribution of Wiwaxia indicates latitudinal control as all occurrences are

obviously restricted to tropical belt.

Oldřich Fatka [atka@natur.cuni.cz] and Petr Kraft [kraft@natur.cuni.cz], Charles University, Institute of Geology and Palaeontology, Albertov 6, 12843 Praha 2, Czech Republic; Michal Szabad [geosz.pb@ seznam.cz],Obránců míru 75, 26102 Př́ibram VII, Czech Republic.

This is an open-access article distributed under the terms of the Creative Commons Attribution License (for details please see creativecommons.org), which permits unrestricted use, distribution, and reproduction in any medium, provided the original author and source are credited. 